Article

\title{
The Effect of Cell Immobilization by Calcium Alginate on Bacterially Induced Calcium Carbonate Precipitation
}

\author{
Mostafa Seifan ${ }^{1, *}$, Ali Khajeh Samani ${ }^{2}$, Shaun Hewitt ${ }^{1}$ and Aydin Berenjian ${ }^{1}$ \\ 1 School of Engineering, Faculty of Science and Engineering, The University of Waikato, \\ Hamilton 3216, New Zealand; sjh104@students.waikato.ac.nz (S.H.); aydin.berenjian@waikato.ac.nz (A.B.) \\ 2 School of Engineering, Faculty of Science and Technology, Federation University, Ballarat 3350, Australia; \\ a.samani@federation.edu.au \\ * Correspondence: ms399@students.waikato.ac.nz
}

Received: 18 October 2017; Accepted: 28 October 2017; Published: 30 October 2017

\begin{abstract}
Microbially induced mineral precipitation is recognized as a widespread phenomenon in nature. A diverse range of minerals including carbonate, sulphides, silicates, and phosphates can be produced through biomineralization. Calcium carbonate $\left(\mathrm{CaCO}_{3}\right)$ is one of the most common substances used in various industries and is mostly extracted by mining. In recent years, production of $\mathrm{CaCO}_{3}$ by bacteria has drawn much attention because it is an environmentally- and health-friendly pathway. Although $\mathrm{CaCO}_{3}$ can be produced by some genera of bacteria through autotrophic and heterotrophic pathways, the possibility of producing $\mathrm{CaCO}_{3}$ in different environmental conditions has remained a challenge to determine. In this study, calcium alginate was proposed as a protective carrier to increase the bacterial tolerance to extreme environmental conditions. The model showed that the highest concentration of $\mathrm{CaCO}_{3}$ is achieved when the bacterial cells are immobilized in the calcium alginate beads fabricated using $1.38 \% w / v$ Na-alginate and $0.13 \mathrm{M} \mathrm{CaCl}_{2}$.
\end{abstract}

Keywords: bacteria; biomineralization; calcium alginate; calcium carbonate; concrete; immobilization; microbially induced calcium carbonate precipitation; ureolysis

\section{Introduction}

Calcium carbonate $\left(\mathrm{CaCO}_{3}\right)$ comprises more than $4 \%$ of the earth's crust. It can be found throughout the world in natural forms such as mArble and limestone. $\mathrm{CaCO}_{3}$ is used in mAny industrial applications and mostly extracted by mining or quarrying. However, large scale industrial mining can be a serious risk to the environment. In recent years, microbially induced $\mathrm{CaCO}_{3}$ precipitation has emerged as an alternative approach to conventional $\mathrm{CaCO}_{3}$ extraction by mining. Bacterially induced $\mathrm{CaCO}_{3}$ precipitation has been successfully used for a wide range of applications including strengthening of sand and soil [1-4], removal of metal contaminants from the soil and groundwater [5], removal of calcium ions and polychlorinated biphenyls [6], remediation of monuments [7], $\mathrm{CO}_{2}$ sequestration [8], bio-deposition on porous mAterials such as limestone and brick $[9,10]$, and, more recently, durability improvement of cementitious mAterials such as concrete [11-13].

Concrete is one of the most popular construction mAterials due to its availability, high compressive strength capacity, and relatively low cost. However, crack formation is the mAin issue associated with concrete structures. Low tensile strength coupled with internal and external stresses are recognized as the key causes of crack formation. Although the embedment of reinforcement bars limits the rate of crack growth, it cannot stop crack initiation in concrete. The initiated cracks accelerate structure degradation by allowing aggressive chemicals (fluids and gasses) to seep into the mAtrix [14]. 
This phenomenon brings about a reduction in concrete service life, increases mAintenance costs, and, in severe cases, leads to structural failure. To replace concrete structures that failed due to cracking, more cement must be produced. Cement is the mAin ingredient of a concrete mixture and its production has a significant impact on the environment. Currently there are different types of techniques to seal the generated cracks. The application of chemical sealants is one of the most frequently used techniques for sealing the detected cracks. However, it has been reported that these mAterials are not environmentally friendly or permanent, and more importantly, they are applicable only for reachable cracks.

Recently, a biotechnological approach has been proposed as a green and viable approach to heal concrete cracks. In this approach, a bio agent containing bacteria and nutrient is incorporated in the concrete. When a crack occurs, $\mathrm{CaCO}_{3}$ precipitation is induced as a result of bacterial metabolic activity and the crack is bridged. Although the biotechnological approach seems to have potential for designing self-healing applications, there are a few challenges left to be addressed. One of the mAin issues with direct incorporation of bacterial cells into the concrete mixture is the high $\mathrm{pH}$ of concrete ( 12). Our previous investigation showed that the bacterial viability decreases when they are exposed to a high $\mathrm{pH}$ environment (concrete $\mathrm{pH}$ ) [15]. The same observation was noticed by Jonkers et al. [16] when free-floating bacteria were mixed with concrete ingredients. Shear forces on the bacterial cells during concrete mixing and casting, as well as shear and compressive stresses during gradual shrinkage of the concrete, could also damage the bacterial cells and negatively influence the performance of the self-healing mechanism. Water activity is another key stress parameter that $\mathrm{mAy}$ influence the bacterial metabolic activity in the concrete environment. It is known that different genera of bacteria have different water activity limits and solute tolerance [17]. Each bacterium has a very specific and narrow water activity for optimum metabolism and growth [18]. More recent studies show that Bacilli and closely related bacteria are moderately xerotolerant $[19,20]$. For near future applications of bio self-healing concrete, it is necessary to design a mAtrix capable of shielding the cells in a concrete environment.

Immobilization of bacterial cells into protective carriers can be a solution to increase the survival of cells in the concrete mAtrix. The encapsulation of bacterial cells into a polymeric mAtrix such as calcium alginate (Ca-alginate) is a promising example of this kind of solution. Furthermore, with encapsulation there is potential for the encapsulated bacterial cells to be separated and re-used. However, the concentrations of Na-alginate and $\mathrm{CaCl}_{2}$ used to form Ca-alginate significantly influence the permeability and the mAss transfer capability of the beads and, consequently, the biomineralization of $\mathrm{CaCO}_{3}$ is affected.

Therefore, this investigation was performed to determine the optimum concentration of Na-alginate and $\mathrm{CaCl}_{2}$ for enhancing $\mathrm{CaCO}_{3}$ biosynthesis and its future applications in bio self-healing concrete.

\section{Materials and Methods}

\subsection{Chemicals}

In this study, a range of different chemicals were used for bacterial growth and fermentation process. Yeast extract, peptone, and calcium chloride were purchased from Sigma-Aldrich (St. Louis, MO, USA). Sodium alginate (Na-alginate), urea, and glucose were purchased from a domestic supplier.

\subsection{Microorganism and Growth Medium}

Bacillus species (B. sphaericus NZRM 4381 and B. licheniformis ATCC 9789) were chosen from our previous studies since they showed the highest ability to produce $\mathrm{CaCO}_{3}[15,21]$. To rehydrate the isolates, the sterilized growth medium, containing peptone $(0.5 \% w / v)$, glucose $(0.5 \% w / v)$, and yeast 
extract $(0.05 \% w / v)$ was used. Thereafter, the bacterial strains were grown on nutrient agar plate and a sporulation process was performed to obtain a pure suspension of spores.

\subsection{Synthesis of Calcium Alginate and Immobilization Process}

The bacteria cells $(4.5 \% v / v$ each strain) were dispersed in different concentrations of sterile Na-alginate solution (1-3\% w/v). Different concentrations $(0.1-0.3 \mathrm{M})$ of sterile calcium chloride solutions were also prepared. The Na-alginate solution was then polymerized to form a gel. As shown schematically in Figure 1, the cell suspension was extruded through a tube (diameter $0.25 \mathrm{~mm}$ ) and injected through a nozzle into a sterile solution of calcium chloride at a constant rate, while the solution was continuously shaken. The beads were formed upon injection and the bacterial cells were entrapped accordingly. To increase the structural integrity of the fabricated beads, the mixture of calcium chloride was stirred for $20 \mathrm{~min}$. Afterwards, a strainer was used to harvest the immobilized cells.

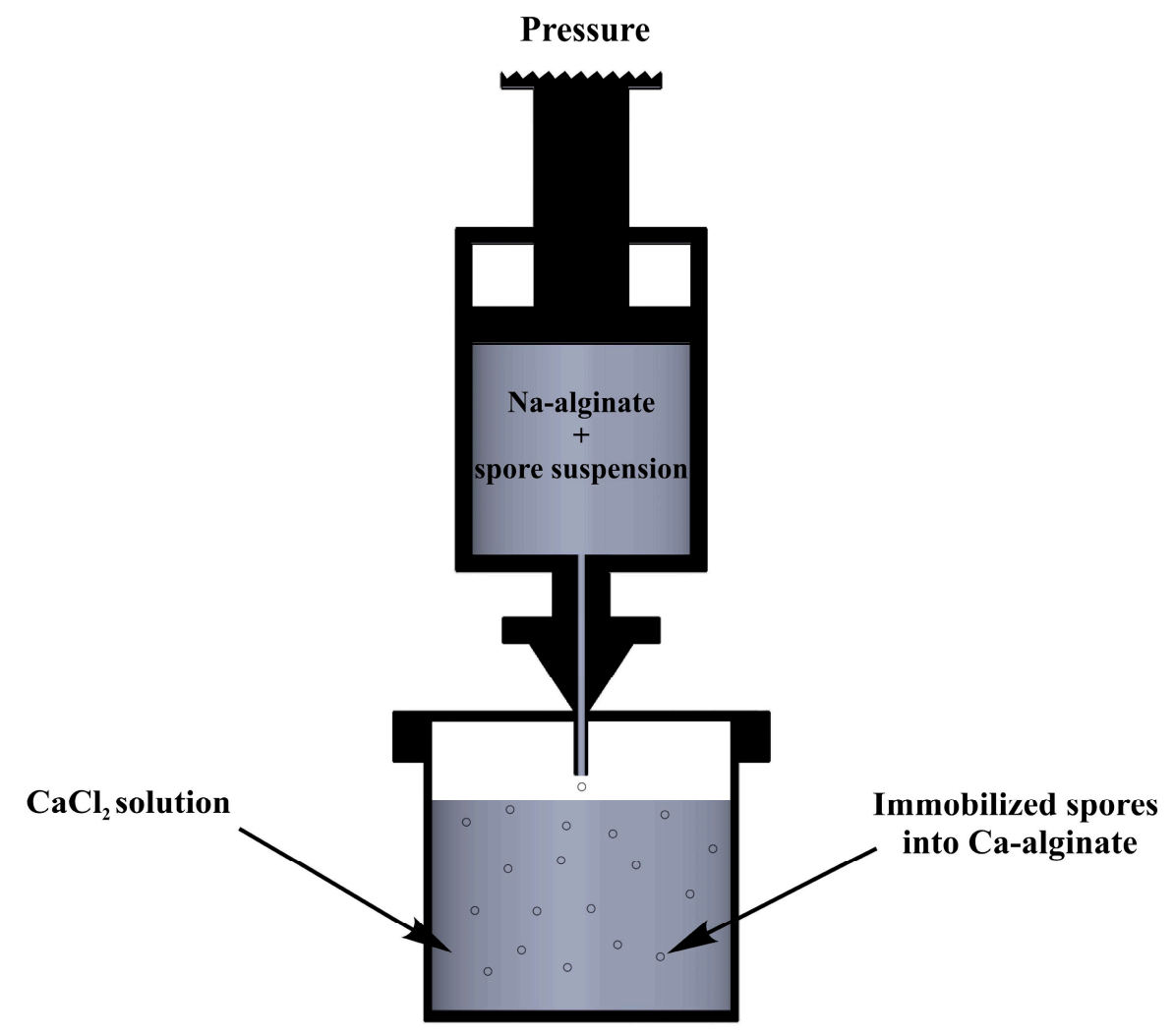

Figure 1. Experimental set up for production of immobilized bacterial cells into Ca-alginate.

\subsection{Experimental Design and Fermentation Procedure}

Statistical software package (MODDE V11, Umetrics, Umeå, Sweden) was used for the optimization study. Response surface methodology (RSM), along with a central composite face-centered (CCF) design mAtrix, was used to determine the optimum concentrations of variables. In the optimization study, a total of 11 experiments were performed with three replications at the center point. The second-order polynomial regression model was employed to fit the experimental data for predicting the resulted biosynthesis product $\left(\mathrm{CaCO}_{3}\right)$, according to Equation (1):

$$
Y=\beta_{0}+\sum \beta_{i} X_{i}+\sum \beta_{i j} X_{i} X_{j}+\sum \beta_{i i} X_{i}^{2}
$$


where $Y$ is the concentration of $\mathrm{CaCO}_{3}$ in $\mathrm{g} / \mathrm{L}, \beta_{0}$ is a constant coefficient, $\beta_{i}, \beta_{i i}$, and $\beta_{i j}$ represent the coefficients of the linear, quadratic, and synergic effects respectively, and $X_{i}$ and $X_{j}$ are the coded values of the significant factors.

In our previous study, the optimum fermentation media and operating conditions to induce the highest concentration of $\mathrm{CaCO}_{3}$ were determined [21]. In the present study, the fermentations were carried out in shaking flasks containing the optimum medium $(40 \mathrm{~g} / \mathrm{L}$ calcium chloride, $65 \mathrm{~g} / \mathrm{L}$ urea, and $2 \mathrm{~g} / \mathrm{L}$ yeast extract). As shown in Table 1, the flasks were then inoculated with the immobilized isolates, mAintained at $35^{\circ} \mathrm{C}$ and $100 \mathrm{rpm}$ for 4.5 days. It is worth noting that the last three experimental runs are the replicates at the center point.

Table 1. Level of variables examined in optimization using central composite face (CCF) design.

\begin{tabular}{cccc}
\hline Experimental Run & Na-Alginate $(w / v)$ & $\mathbf{C a C l}_{\mathbf{2}} \mathbf{( M )}$ & $\mathrm{CaCO}_{\mathbf{3}}(\mathrm{g} / \mathrm{L})$ \\
\hline 1 & 1 & 0.1 & 24.93 \\
2 & 3 & 0.1 & 21.32 \\
3 & 1 & 0.3 & 20.17 \\
4 & 3 & 0.3 & 19.27 \\
5 & 1 & 0.2 & 24.99 \\
6 & 3 & 0.2 & 21.37 \\
7 & 2 & 0.1 & 24.69 \\
8 & 2 & 0.3 & 21.52 \\
9 & 2 & 0.2 & 24.59 \\
10 & 2 & 0.2 & 23.96 \\
11 & 2 & 0.2 & 24.62 \\
\hline
\end{tabular}

\section{5. $\mathrm{CaCO}_{3}$ Extraction}

The soluble calcium contained in the media was determined using a benchtop photometer. The precipitated $\mathrm{CaCO}_{3}$ was harvested by passing through filter paper $(0.2 \mu \mathrm{m})$ and washed three times with distilled water. The precipitates were oven dried at $70^{\circ} \mathrm{C}$ for $24 \mathrm{~h}$.

\subsection{Crystal Characterization and Morphological Observation}

Scanning electron microscopy (SEM) was used for morphological characterization of precipitated $\mathrm{CaCO}_{3}$. The precipitated powder was placed in a carbon tape, and the sample was coated with platinum using a sputter coater (Hitachi E1030, Tokyo, Japan). The sample was mounted into the SEM instrument (Hitachi S-4700, Tokyo, Japan), and crystal observation was performed. The elemental analysis was also performed to analyze the compositions of the mineralization products using energy dispersive $\mathrm{X}$-ray spectroscopy (EDS). SEM imaging and EDS analysis were performed at $5 \mathrm{KeV}$ and $15 \mathrm{KeV}$, respectively.

The collected dry precipitates were well-crushed using a mortar and pestle for X-ray diffraction (XRD) analysis. The powder was then packed into sample holder and analysis was performed using a Panalytical Empyrean diffractometer (Almelo, The Netherlands) with $\mathrm{CuK} \alpha$ radiation. The data were collected for an exploration range, step size, voltage, and current of $15-70^{\circ}(2 \theta), 0.0530^{\circ}, 45 \mathrm{KV}$, and $40 \mathrm{~mA}$, respectively.

\section{Results and Discussion}

\subsection{Immobilization of Bacterial Cell into Ca-Alginate}

Immobilization of bacteria cells can be achieved through four mAin categories, namely: (1) attachment or adsorption onto solid carrier surfaces; (2) entrapment within a porous mAtrix; (3) self-aggregation by flocculation or with crosslinking agents; and (4) cell containment behind barriers [22]. Cell entrapment can be done into polysaccharide gel mAtrices, such as alginates, agar, and chitosan, or other polymeric mAtrixes including gelatin. In this study, polysaccharide 
gel entrapment (Ca-alginate) was used as an efficient immobilization approach to prevent the cells from diffusing into the surroundings. As shown in Figure 2a, the bacterial cells were successfully immobilized into uniformly sized Ca-alginate beads. An ideal immobilization approach must allow the mAss transfer of nutrients to facilitate the bioprocess, while protecting the cells from the surrounding environment. The protective mechanism operates via triggering a stress response that produces a more robust cell. This phenomenon has previously been demonstrated at the level of the mAcromolecule [23]. Figure 2b illustrates the accumulation of bio-precipitates around the Ca-alginate beads in the fermentation media. This shows that that the fabricated Ca-alginate beads with the optimum concentrations of $\mathrm{Na}$-alginate and $\mathrm{CaCl}_{2}$ were sufficiently permeable to promote the biosynthesis.

\subsection{Bacterially Induced $\mathrm{CaCO}_{3}$ Precipitation}

To mAximize $\mathrm{CaCO}_{3}$ precipitation, the immobilization carriers should be permeable, while also being able to prevent cells from diffusing into the fermentation media. As given in Table 1, an optimization study was performed to identify the optimum concentrations of Na-alginate and $\mathrm{CaCl}_{2}$. Apart from the entrapment of the bacterial cells inside the beads, the immobilization into porous mAtrix such as polysaccharide gel can result in the bacterial cells moving to the outer surface of the beads. However, the effect the immobilization $m$ Ay influence the water activity, and as consequence metabolism will be affected [24].

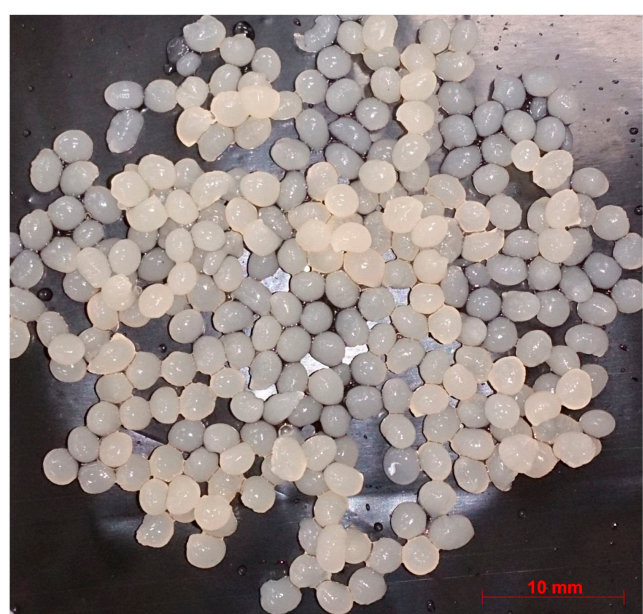

(a)

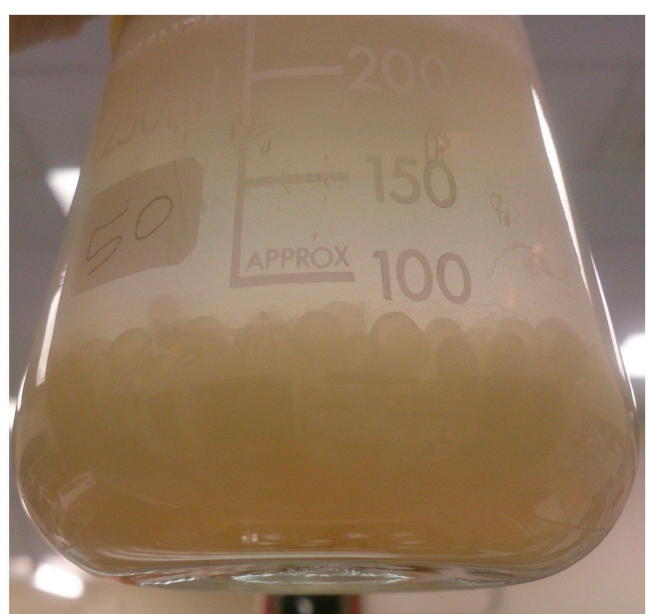

(b)

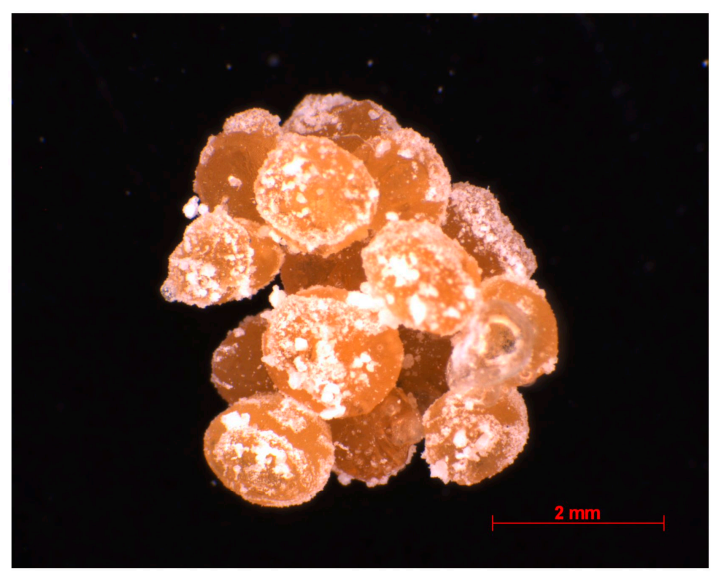

(c)

Figure 2. (a) Immobilized bacterial cells into Ca-alginate beads; (b) fermentation medium inoculated with immobilized bacterial cells; and (c) precipitated $\mathrm{CaCO}_{3}$ crystals around Ca-alginate beads. 
In Figure 3, a 3D response surface plot was constructed to illustrate the synergistic effects of Na-alginate and $\mathrm{CaCl}_{2}$ concentrations on the response $\left(\mathrm{CaCO}_{3}\right)$ and also provide a visual interpretation for the location of the optimal concentrations. The shape of the corresponding plots shows that the mutual interaction between variables is significant, and the response was considerably affected by the concentrations of $\mathrm{Na}$-alginate and $\mathrm{CaCl}_{2}$.

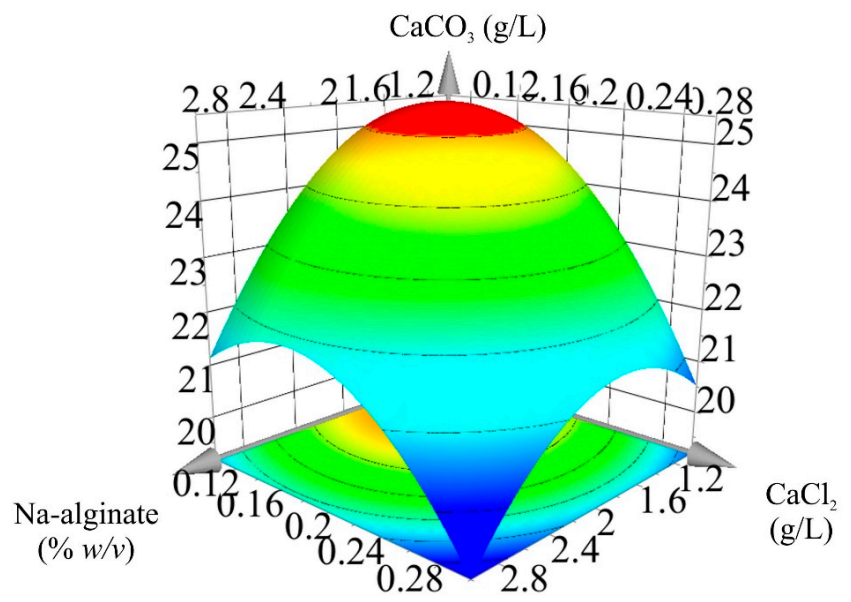

Figure 3. $3 \mathrm{D}$ response surface plot showing the interactive effects of $\mathrm{Na}$-alginate and $\mathrm{CaCl}_{2}$ for bacterially induced $\mathrm{CaCO}_{3}$ precipitation.

To investigate the optimum levels of variables on the biosynthesis process, RSM, using a CCF design mAtrix, was used. The statistical analysis data containing the regression coefficients for the model are given in Table 2. As shown in Equation (2), a quadratic model was regressed for predicting the $\mathrm{CaCO}_{3}$ precipitation.

$$
Y=24.49-1.36 X_{1}-1.67 X_{2}-1.46 X_{1}^{2}-1.54 X_{2}^{2}+0.68 X_{1} X_{2}
$$

where $Y, X_{1}$, and $X_{2}$ represent the predicted $\mathrm{CaCO}_{3}$ concentration, Na-alginate concentration, and $\mathrm{CaCl}_{2}$ concentration, respectively. The statistical analysis of the quadratic regression model shows that the model is significant $(p$-value $<0.05)$, with $R^{2}$ value of 0.977 . Based on the results, all the single, linear, and quadratic terms are significant on $\mathrm{CaCO}_{3}$ precipitation. The statistical significance of the quadratic model was checked by F-test, and the results of analysis of variance (ANOVA) are listed in Table 3. The model was assessed for suitability by examining misfit, which was found insignificant for the model $(p$-value $<0.05)$. Lack of fit is used to evaluate the accuracy of the fitted model. When a mAthematical model is well-fitted to the experimental results, the mean squared lack of fit reflects only the random errors inherent to the system [25]. According to the ANOVA results, the non-significant lack of fit $(p$-value $<0.367)$ and a significant regression $(p$-value $<0.000)$ suggest the high accuracy of the fitted model.

Table 2. Statistical analysis from the central composite face-centered (CCF) design experiments for $\mathrm{CaCO}_{3}$ precipitation.

\begin{tabular}{cccc}
\hline Terms & Coefficient & Std. Err. ${ }^{*}$ & $p$-Value \\
\hline Constant & 24.493 & 0.236 & 0.000 \\
$X_{1}$ & -1.355 & 0.187 & 0.000 \\
$X_{2}$ & -1.663 & 0.187 & 0.000 \\
$X_{1}{ }^{2}$ & -1.459 & 0.289 & 0.004 \\
$X_{2}{ }^{2}$ & -1.537 & 0.289 & 0.003 \\
$X_{1} \cdot X_{2}$ & 0.676 & 0.230 & 0.032 \\
\hline
\end{tabular}

* Std. Err. $=$ Standard error, $X_{1}=$ Na-alginate, $X_{2}=\mathrm{CaCl}_{2}, R^{2}=0.977$ and $R^{2}$ (adj.) $=0.954$. 
Table 3. Analysis of variance for $\mathrm{CaCO}_{3}$ precipitation.

\begin{tabular}{ccccccc}
\hline Source of Variation & DF $^{*}$ & SS $^{*}$ & MS (Variance) & $\boldsymbol{F}$-Value & $p$-Value & SD $^{*}$ \\
\hline Total & 11 & 5793.834 & 526.712 & - & - & - \\
Constant & 1 & 5747.827 & 5747.827 & - & - & - \\
Total corrected & 10 & 46.007 & 4.601 & - & - & 2.145 \\
Regression & 5 & 44.949 & 8.990 & 42.47 & 0.000 & 2.998 \\
Residual & 5 & 1.058 & 0.212 & - & - & 0.460 \\
Lack of Fit & 3 & 0.780 & 0.260 & 1.868 & 0.367 & 0.510 \\
Pure error & 2 & 0.278 & 0.139 & - & - & 0.373 \\
\hline
\end{tabular}

${ }^{*} \mathrm{DF}=$ Degrees of freedom, $\mathrm{SS}=$ Sum of squares, MS = Mean square and SD = Standard error.

To determine the optimum levels of $\mathrm{Na}$-alginate and $\mathrm{CaCl}_{2}$, the regression equations were solved within the experimental region. Independent fermentation runs were carried out at the conditions predicted by the model to verify the optimization results. The fermented medium was supplemented with the optimum concentrations of variables $(1.38 \% w / v \mathrm{Na}$-alginate and $0.13 \mathrm{M}$ $\left.\mathrm{CaCl}_{2}\right)$. The optimization shows that the highest concentration of $\mathrm{CaCO}_{3}(25.48 \mathrm{~g} / \mathrm{L})$ is achieved when the optimal concentrations of Na-alginate and $\mathrm{CaCl}_{2}$ are used.

\subsection{Morphological Observation and Crystal Characterization}

Calcite, aragonite, and vaterite are three crystalline polymorphs of $\mathrm{CaCO}_{3}$ found existing naturally. In general, physical and chemical characteristics of $\mathrm{CaCO}_{3}$ precipitates such as crystal size, specific surface area, morphology, purity, and brightness are the mAin criteria that are usually considered for industrial applications. Physical properties of $\mathrm{CaCO}_{3}$, including density, solubility, and hardness, largely depend on the fraction of each polymorph. Bioprecipitation of $\mathrm{CaCO}_{3} \mathrm{mAy}$ result in the production of multiple different polymorphs. As vaterite has a lower density than calcite, a higher volume can be filled when vaterite particles are induced in a concrete crack, which contributes to enhancing the effectiveness of the self-healing mechanism.

SEM and XRD analysis were used to determine the morphology of precipitated $\mathrm{CaCO}_{3}$ crystals. Figure 4a presents an assemblage of vaterite particles produced through biomineralization via bacterial cells immobilized in Ca-alginate beads. The elemental compositions of the bioproducts were determined by EDS, and the spectra are given in Figure $4 \mathrm{~b}$. The results show that $\mathrm{Ca}, \mathrm{O}$, and $\mathrm{C}$ are the $\mathrm{mAin}$ elements found in the biominerals. The elemental ratios of the detected elements are very close to the pure $\mathrm{CaCO}_{3}$, and this confirms that the precipitated crystals are $\mathrm{CaCO}_{3}$. The XRD spectra for the $\mathrm{CaCO}_{3}$ crystals produced during fermentation are shown in Figure 5. The XRD spectra indicate that vaterite and calcite were the most predominant polymorphs produced when the media was inoculated with immobilized bacteria cells. The results also demonstrate that the immobilization had no significant effect on $\mathrm{CaCO}_{3}$ morphology. This means that this approach can be used as a promising tool for protecting bacterial cells in a harsh environment without influencing the metabolic activity.

The reason for the production of different polymorphs during biosynthesis of $\mathrm{CaCO}_{3}$ is not well established. Different parameters such as media compositions, cell surface characteristics, bacteria metabolic activities, and extracellular polymeric substance (EPS) have been demonstrated to have an effect on the morphology of the precipitated particles [21]. The results obtained in this study show that the immobilization of bacteria in Ca-alginate beads is a promising approach to enhance the cell protection and recovery. This provides a new protocol to address the shortcomings associated with the future application of sustainable bio self-healing concrete. 


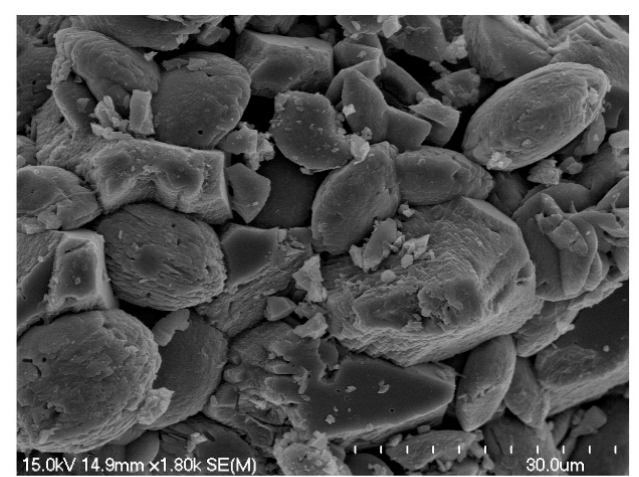

(a)

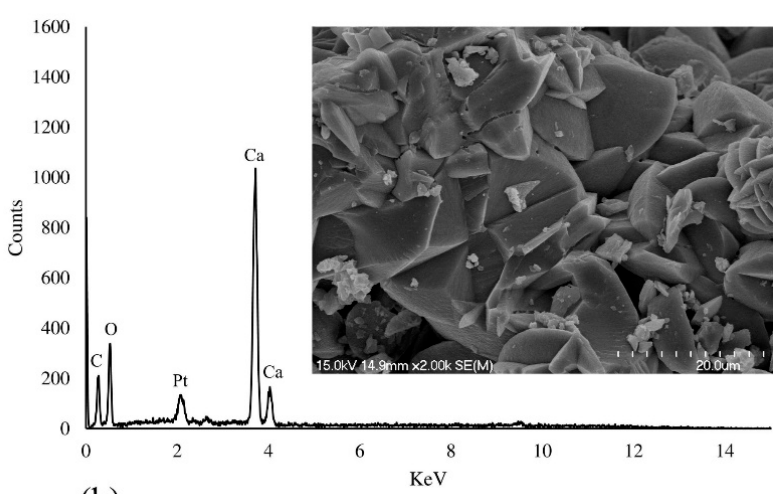

(b)

Figure 4. (a) Scanning electron microscopy (SEM) micrograph of precipitated $\mathrm{CaCO}_{3}$ crystals using immobilized bacterial cells into Ca-alginate and (b) energy dispersive X-ray spectroscopy (EDS) spectra of the induced $\mathrm{CaCO}_{3}$ crystal.

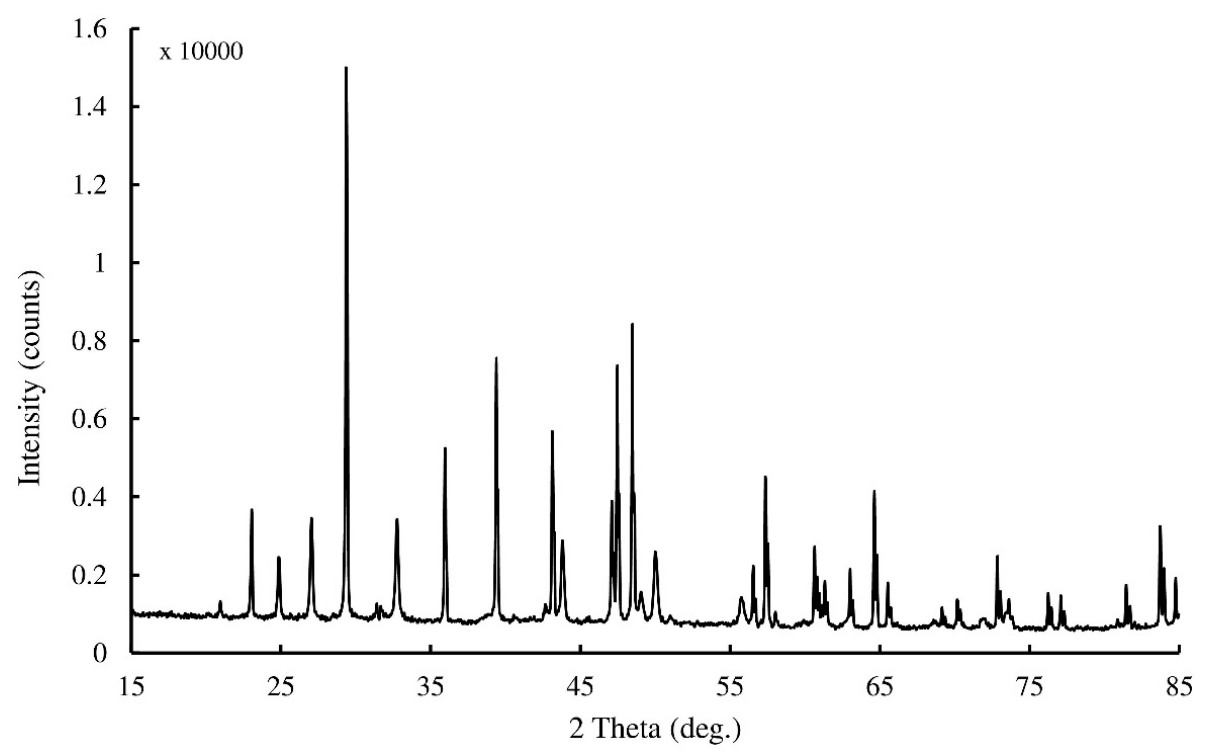

Figure 5. X-ray diffraction (XRD) spectra for the precipitated $\mathrm{CaCO}_{3}$ precipitation via immobilized bacterial cells into Ca-alginate beads.

\section{Conclusions}

The immobilization of Bacillus species in a polymeric mAtrix (Ca-alginate) proved a promising technique not only for protecting the bacterial cells from harsh environments but also for ease of separation and recovery. The model indicates that the implementation of the optimal concentrations of Na-alginate $(1.38 \% w / v)$ and $\mathrm{CaCl}_{2}(0.13 \mathrm{M})$ results in the highest $\mathrm{CaCO}_{3}$ precipitation. Moreover, crystal characterization demonstrated that the entrapment of bacterial cells into Ca-alginate has no effect on the $\mathrm{CaCO}_{3}$ morphology formed. The results of this study can also be used for processing with recycled bacterial capsules by reducing the downstream processes involved.

Acknowledgments: This investigation was financially supported by The University of Waikato, New Zealand.

Author Contributions: Mostafa Seifan and Aydin Berenjian conceived the experiments and analyzed the data; Mostafa Seifan performed the experiments and wrote the mAnuscript; Aydin Berenjian and Shaun Hewitt revised the mAnuscript; Ali Khajeh Samani contributed analysis tools.

Conflicts of Interest: The authors declare no conflict of interest. 


\section{References}

1. Van Paassen, L.A.; Daza, C.M.; Staal, M.; Sorokin, D.Y.; van der Zon, W.; van Loosdrecht, M.C.M. Potential soil reinforcement by biological denitrification. Ecol. Eng. 2010, 36, 168-175. [CrossRef]

2. Whiffin, V.S.; van Paassen, L.A.; Harkes, M.P. Microbial carbonate precipitation as a soil improvement technique. Geomicrobiol. J. 2007, 24, 417-423. [CrossRef]

3. Burbank, M.B.; Weaver, T.J.; Green, T.L.; Williams, B.; Crawford, R.L. Precipitation of calcite by indigenous microorganisms to strengthen liquefiable soils. Geomicrobiol. J. 2011, 28, 301-312. [CrossRef]

4. Cheng, L.; Cord-Ruwisch, R. Upscaling effects of soil improvement by microbially induced calcite precipitation by surface percolation. Geomicrobiol. J. 2014, 31, 396-406. [CrossRef]

5. Warren, L.A.; mAurice, P.A.; Parmar, N.; Ferris, G.F. Microbially mediated calcium carbonate precipitation: Implications for interpreting calcite precipitation and for solid-phase capture of inorganic contaminants. Geomicrobiol. J. 2001, 18, 93-115.

6. Dhami, N.K.; Reddy, M.S.; Mukherjee, A. Biomineralization of calcium carbonates and their engineered applications: A review. Front. Microbiol. 2013, 4. [CrossRef] [PubMed]

7. Tiano, P.; Biagiotti, L.; mAstromei, G. Bacterial bio-mediated calcite precipitation for monumental stones conservation: Methods of evaluation. J. Microbiol. Methods 1999, 36, 139-145. [CrossRef]

8. Okyay, T.O.; Rodrigues, D.F. Biotic and abiotic effects on $\mathrm{CO}_{2}$ sequestration during microbially-induced calcium carbonate precipitation. FEMS Microbiol. Ecol. 2015, 91. [CrossRef] [PubMed]

9. De Muynck, W.; Leuridan, S.; Van Loo, D.; Verbeken, K.; Cnudde, V.; De Belie, N.; Verstraete, W. Influence of pore structure on the effectiveness of a biogenic carbonate surface treatment for limestone conservation. Appl. Environ. Microbiol. 2011, 77, 6808-6820. [CrossRef] [PubMed]

10. Dhami, N.K.; Reddy, M.S.; Mukherjee, A. Improvement in strength properties of ash bricks by bacterial calcite. Ecol. Eng. 2012, 39, 31-35. [CrossRef]

11. Sierra-Beltran, M.G.; Jonkers, H.M.; Schlangen, E. Characterization of sustainable bio-based mortar for concrete repair. Constr. Build. mAter. 2014, 67, 344-352. [CrossRef]

12. Van Tittelboom, K.; De Belie, N.; De Muynck, W.; Verstraete, W. Use of bacteria to repair cracks in concrete. Cem. Concr. Res. 2010, 40, 157-166. [CrossRef]

13. Seifan, M.; Samani, A.K.; Berenjian, A. Bioconcrete: Next generation of self-healing concrete. Appl. Microbiol. Biotechnol. 2016, 100, 2591-2602. [CrossRef] [PubMed]

14. Seifan, M.; Samani, A.K.; Burgess, J.J.; Berenjian, A. The effectiveness of microbial crack treatment in self healing concrete. In High Value Processing Technologies; Berenjian, A., Jafarizadeh-Malmiri, H., Song, Y., Eds.; Nova Science Publishers Inc.: New York, NY, USA, 2016; pp. 97-124.

15. Seifan, M.; Samani, A.K.; Berenjian, A. New insights into the role of $\mathrm{pH}$ and aeration in the bacterial production of calcium carbonate $\left(\mathrm{CaCO}_{3}\right)$. Appl. Microbiol. Biotechnol. 2017, 101, 3131-3142. [CrossRef] [PubMed]

16. Jonkers, H.M.; Thijssen, A.; Muyzer, G.; Copuroglu, O.; Schlangen, E. Application of bacteria as self-healing agent for the development of sustainable concrete. Ecol. Eng. 2010, 36, 230-235. [CrossRef]

17. Stevenson, A.; Cray, J.A.; Williams, J.P.; Santos, R.; Sahay, R.; Neuenkirchen, N.; McClure, C.D.; Grant, I.R.; Houghton, J.D.; Quinn, J.P. Is there a common water-activity limit for the three domains of life? ISME J. 2015, 9, 1333-1351. [CrossRef] [PubMed]

18. Stevenson, A.; Burkhardt, J.; Cockell, C.S.; Cray, J.A.; Dijksterhuis, J.; Fox-Powell, M.; Kee, T.P.; Kminek, G.; McGenity, T.J.; Timmis, K.N. Multiplication of microbes below 0.690 water activity: Implications for terrestrial and extraterrestrial life. Environ. Microbiol. 2015, 17, 257-277. [CrossRef] [PubMed]

19. Stevenson, A.; Hallsworth, J.E. Water and temperature relations of soil actinobacteria. Environ. Microbiol. Rep. 2014, 6, 744-755. [CrossRef] [PubMed]

20. Cray, J.A.; Connor, M.C.; Stevenson, A.; Houghton, J.D.; Rangel, D.E.; Cooke, L.R.; Hallsworth, J.E. Biocontrol agents promote growth of potato pathogens, depending on environmental conditions. Microb. Biotechnol. 2016, 9, 330-354. [CrossRef] [PubMed]

21. Seifan, M.; Samani, A.K.; Berenjian, A. Induced calcium carbonate precipitation using Bacillus species. Appl. Microbiol. Biotechnol. 2016, 100, 9895-9906. [CrossRef] [PubMed] 
22. Kourkoutas, Y.; Bekatorou, A.; Banat, I.M.; mArchant, R.; Koutinas, A.A. Immobilization technologies and support mAterials suitable in alcohol beverages production: A review. Food Microbiol. 2004, 21, 377-397. [CrossRef]

23. Bell, A.N.; mAgill, E.; Hallsworth, J.E.; Timson, D.J. Effects of alcohols and compatible solutes on the activity of $\beta$-galactosidase. Appl. Biochem. Biotechnol. 2013, 169, 786-794. [CrossRef] [PubMed]

24. Cray, J.A.; Stevenson, A.; Ball, P.; Bankar, S.B.; Eleutherio, E.C.; Ezeji, T.C.; Singhal, R.S.; Thevelein, J.M.; Timson, D.J.; Hallsworth, J.E. Chaotropicity: A key factor in product tolerance of biofuel-producing microorganisms. Curr. Opin. Biotechnol. 2015, 33, 228-259. [CrossRef] [PubMed]

25. Bezerra, M.A.; Santelli, R.E.; Oliveira, E.P.; Villar, L.S.; Escaleira, L.A. Response surface methodology (rsm) as a tool for optimization in analytical chemistry. Talanta 2008, 76, 965-977. [CrossRef] [PubMed]

(C) 2017 by the authors. Licensee MDPI, Basel, Switzerland. This article is an open access article distributed under the terms and conditions of the Creative Commons Attribution (CC BY) license (http:/ / creativecommons.org/licenses/by/4.0/). 